
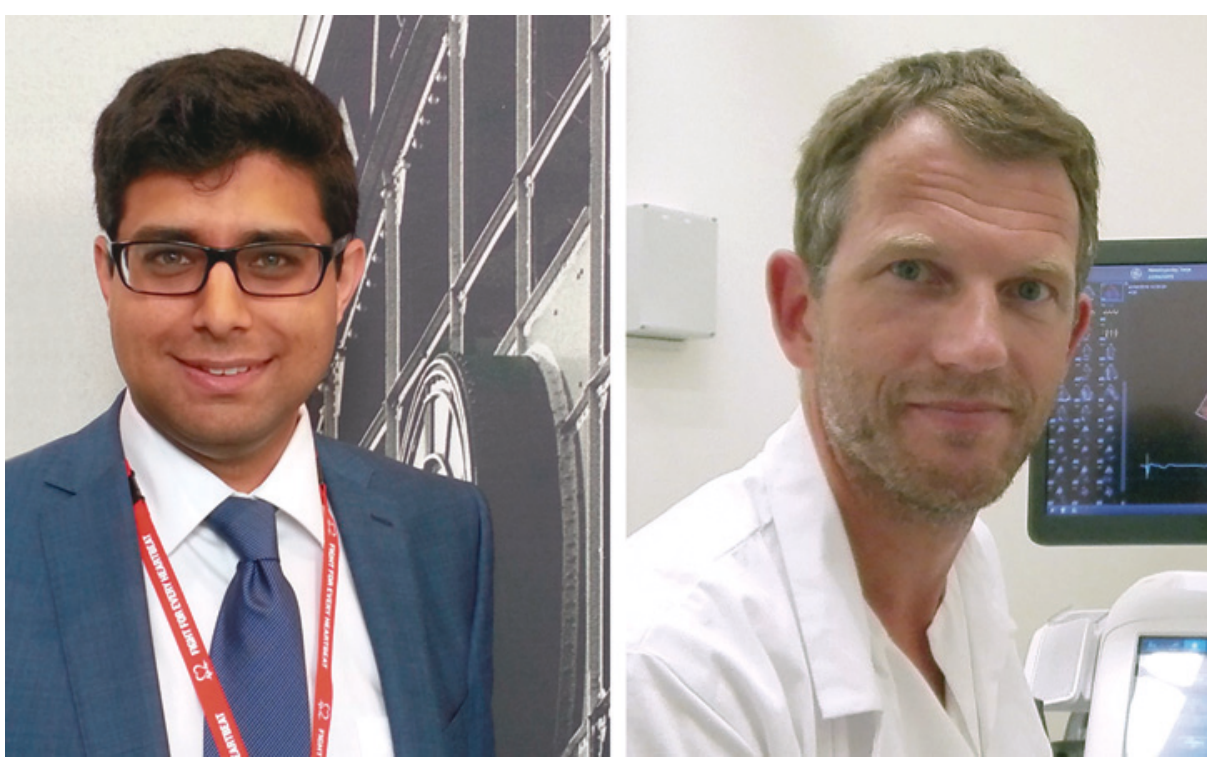

Førsteforfatter Dipak Kotecha og medforfatter Thomas von Lueder. Foto: Privat

\title{
Hjertesviktpasienter med sinusrytme bør få betablokker
}

Betablokkere bør brukes hos alle hjertesviktpasienter med sinusrytme, uavhengig av alder og kjønn, viser en studie publisert i BMJ.

Betablokkere er en viktig del av behandlingen til mange hjertesviktpasienter med sinusrytme. En internasjonal forskergruppe med deltagelse fra Oslo universitetssykehus har nylig publisert en stor multisenterstudie der effekten av betablokkere hos denne pasientgruppen er undersøkt (1).

Studien er basert på data om nesten 14000 hjertesviktpasienter ( $76 \%$ menn) med nedsatt ejeksjonsfraksjon $($ dvs. $<0,45)$ og sinusrytme fra 11 enkeltstudier. Pasientene var randomisert til behandling med enten betablokker eller placebo. Gjennomsnittsalderen var 64 år.

Dødeligheten i alle alderskvartiler var signifikant redusert ved bruk av betablokker i alle alderskvartiler, med hasardratio på henholdsvis $0,66,0,71,0,65$ og $0,77 \mathrm{i}$ fra nedre til øvre alderskvartil. Den absolutte mortalitetsreduksjonen etter 16 måneders oppfølging var 4,3\%. Effekten var lik for begge kjønn. Lignende effekter ble vist for innleggelse for hjertesvikt, som var studiens sekundære endepunkt.

- Denne studien viser at betablokkere er effektivt hos alle hjertesviktpasienter med sinusrytme, uansett alder og kjønn, sier medforfatter Thomas von Lueder ved Oslo universitetssykehus, Ullevål. - Frykten for bivirkninger og lavere effektivitet, særlig hos eldre og kvinner, er oftest ubegrunnet. Denne studien avkrefter noen av mytene i hjertesviktbehandling og kan før til bedre behandling, sier von Lueder.

\section{Internasjonalt samarbeid om hjertesvikt}

Beta-Blockers in Heart Failure Collaborative Group ble stiftet i 2008. Arbeidet med databasen med individuelle pasientdata ledes av Dipak Kotecha i Birmingham. Databasen ble ferdigstilt 2014, og ut fra den skal man belyse relevante spørsmål rundt bruk av betablokkere ved hjertesvikt. Gruppen består av forskere bak originalstudiene og forskere fra ledende hjertesviktmiljøer. von Lueder bidro til databasen med bl.a. pasientdata fra The Cardiac Insufficiency Bisoprolol Study. Han er eneste norske medforfatter.

\section{Kaveh Rashidi}

Tidsskriftet

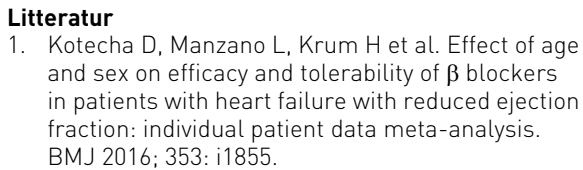

1. Kotecha D, Manzano L, Krum $\mathrm{H}$ et al. Effect of age and sex on efficacy and tolerability of $\beta$ blockers in patients with heart failure with reduced ejection fraction: individual patient data meta-analysis. BMJ 2016; 353: i1855.

Ordforklaringer

Hjertesvikt: En tilstand der hjertets pumpeevne og/eller fyllingsevne er svekket. Hjertesvikt deles vanligvis inn etter om det er systolisk (pumpeevnen) eller diastolisk (fyllingsevnen) funksjon som er redusert.

Betablokkere ( $\beta$-blokkere): Dette er en gruppe legemidler som blant annet brukes ved hjertesvikt, hjerteinfarkt, høyt blodtrykk og hjerterytmeforstyrrelser.
Artikkelen ble publisert i det prestisjetunge tidsskriftet BMJ i april 2016 